\title{
Rules of Origin in Services: A Case Study of Five ASEAN Countries
}

\author{
By Carsten Fink and Deunden Nikomborirak ${ }^{*}$
}

\begin{abstract}
Non-technical abstract
An important question in the design of bilateral and regional free trade agreements covering services is to what extent non-members benefit from the trade preferences that are negotiated among members. This question is resolved through services rules of origin. The restrictiveness of rules of origin determines the degree of preferences entailed in market opening commitments, shaping the bargaining incentives of FTAs and their eventual economic effects.

Even though the number of FTAs in services has increased rapidly in recent years, hardly any research is available that can guide policymakers on the economic implications of different rules of origin. After outlining the key economic trade-offs and options for rules of origin in services, the paper summarizes the main findings of a research project that has assessed the rules of origin question for five countries in the ASEAN region. For selected service sub-sectors and a number of criteria for rules or origin, simulation exercises evaluated which service providers would or would not be eligible for preferences negotiated under an FTA. Among other findings, the simulation results point to the binding nature of a domestic ownership or control requirement and, for the specific case of financial services, a requirement of incorporation.
\end{abstract}

World Bank Policy Research Working Paper 4130, February 2007

The Policy Research Working Paper Series disseminates the findings of work in progress to encourage the exchange of ideas about development issues. An objective of the series is to get the findings out quickly, even if the presentations are less than fully polished. The papers carry the names of the authors and should be cited accordingly. The findings, interpretations, and conclusions expressed in this paper are entirely those of the authors. They do not necessarily represent the view of the World Bank, its Executive Directors, or the countries they represent. Policy Research Working Papers are available online at http://econ.worldbank.org.

\footnotetext{
* Carsten Fink is a Senior Economist at the World Bank Institute. Deunden Nikomborirak is Research Director at the Thailand Development Research Institute (TDRI). This paper is forthcoming in the book Trade in Services: New Perspectives on Liberalization, Regulation, and Development, edited by Marion Panizzon, Nicole Pohl, and Pierre Sauvé (Cambridge: Cambridge University Press). It is based on a research project on rules of origin in services undertaken by the ASEAN Economic Forum research network and supported by the World Bank Institute. The authors are grateful to George Manzano, Pierre Sauvé and participants at the World Trade Forum 2006 for helpful comments and suggestions.
} 


\section{Introduction}

The number of bilateral and regional free trade agreements (FTAs) involving members of the Association of South East Asian Nations (ASEAN) is increasing at a mind-boggling pace. Table 1 offers an overview of agreements in which at least one ASEAN country participates. All of these agreements seek the liberalization of trade in services, at a faster pace than what is foreseen under the WTO’s General Agreement on Trade in Services (GATS).

An important question in the design of FTAs covering services is to what extent non-members benefit from the trade preferences that are negotiated among members. This question is resolved through so-called rules of origin (sometimes also referred to as denial of benefit). The restrictiveness of rules of origin determines the degree of preferences entailed in market opening commitments, shaping the bargaining incentives of FTAs and their eventual economic effects.

Notwithstanding the conclusion of many new FTAs, hardly any research is available that can guide policymakers on the economic implications of different rules of origin. This paper summarizes the main findings of a research project that investigated some of these implications for five ASEAN countries: Laos, Malaysia, the Philippines, Thailand, and Vietnam. In particular, for selected service sub-sectors and a number of criteria for rules or origin, national research studies in these countries simulated which service providers would or would not be eligible for preferences negotiated under an FTA.

The paper is structured as follows. We first describe the rules of origin question in greater detail, explain why it is important, what different options for rules of origin exist, and what factors determine the relevance and restrictiveness of rules of origin. Based on this discussion, we then summarize the main findings of the national research studies. The final section offers concluding remarks.

\section{Rules of origin in services: conceptual issues}

\section{What are rules of origin in services?}

Rules of origin have long been a prominent issue in the case of goods trade. In the goods case, they seek to prevent the transshipment of goods for the sole purpose of obtaining preferential tariff treatment under an FTA. This case is illustrated in Figure 1. Suppose countries A and B sign a trade agreement that eliminates tariffs on all trade between the two countries. Suppose also that country A's remaining tariff for imports from the rest of the world-its most favored nation (MFN) tariff-is lower than country B's MFN tariff. Ignoring transport costs, exporters from the rest of the world would have an incentive to transship their exports to country B through country A and thereby avoid paying country B's higher tariff. If this were possible, an FTA would de facto reduce member countries' external tariffs to the lowest MFN rate in the FTA area. To allow varying MFN tariff rates among FTA members, FTAs need to establish rules of origin that define the level of transformation imported goods need to undergo, in order for the transformed product to be exported to the FTA partner at the preferential tariff. 
What is different about trade in services? One important difference is that protection in services does not take the form of tariffs, but is exercised through a class of non-tariff measures, ranging from quantitative limitations to regulatory restrictions. Nonetheless, for some forms of services trade, the issue is broadly similar. Consider the supply of cross-border call center services. Suppose two countries form an FTA that eliminates a ban on the cross-border provision of these services. Would a supplier in one member country be allowed to offer call center services to the other member, if the supplier sub-contracted these services further to a company located in a third country, not party to the FTA? What level of 'service transformation' would need to take place for a call center service imported into an FTA member to qualify for trade preferences?

Interestingly, this question is only beginning to receive attention in trade agreements. This may be partly because the notions of imported intermediated inputs and domestic value added are not as well-developed in services as they are in the goods context. It may also be because this form of trade has, so far, been largely unrestricted. However, in view of the rapid growth of crossborder trade in services, the imposition of trade barriers may well be conceivable in future (see Mattoo and Wunsch, 2004). ${ }^{1}$ Indeed, the recent bilateral trade agreement of Singapore with Japan contains language that could be construed as a restrictive rule of origin for cross-border trade in services. ${ }^{2}$

Notwithstanding these more recent developments, the focus of rules of origin in services trade agreements has, so far, been a different one. Rather than defining the origin of a service, they have sought to delineate the origin of a service supplier. This is largely due to the inherent characteristics of services. Most services require the physical proximity between the supplier and consumer of the service and therefore cannot be traded cross-border. For example, a haircut service cannot be supplied remotely and can therefore also not be "transshipped" through a third country. For precisely this reason, trade agreements typically adopt a wide definition of trade in services to include the purchase of services by consumers moving to the country of the producer (Mode 2 trade) and the sale of services by producers moving to the country of the consumer. The latter case includes the establishment of a commercial presence by services firms (Mode 3 trade) and the movement of individual service suppliers (Mode 4 trade).

The rule of origin question for service suppliers is illustrated in Figure 2-both for the case of companies (juridical persons) and individuals (natural persons). In the case of juridical persons, suppose a company from the rest of the world establishes a commercial presence in country A. Under what circumstances would the subsidiary or branch established in country A benefit from trade preferences under the FTA, if it wishes to supply services to country B? Note that this question is relevant for service exports supplied through Modes 1, 2, and 3. In the case of natural persons, suppose an individual from the rest of the world relocates to country A. Under

\footnotetext{
${ }^{1}$ The question of rules of origin for cross border trade is far from theoretical. Suppose the US imposed restrictions on outsourcing business services to India-as has been considered by a number of US states. The US would be free to do so for every sub-sector not currently scheduled as unrestricted under the GATS. Would it be possible for Indian companies to supply these services through an affiliated or unaffiliated company in Mexico, taking advantage of the liberal market access conditions provided for under NAFTA's negative list in services?

${ }^{2}$ Following GATS Article XXVII, Article 70(a) of the Singapore-Japan FTA enables a party to deny the benefits of the services chapter "to the supply of any service, if it establishes that the service is supplied from or in the territory of a non-Party [...]".
} 
what circumstances would this individual benefit from the trade preferences on Mode 4 negotiated under the FTA?

\section{Why is the rules of origin question important?}

Rules of origin in services determine the extent of preferences entailed in market opening commitments that countries undertake in FTAs. A liberal rule of origin enables service providers from non-member countries to benefit from improved market access negotiated under an FTA. Such a rule still falls short of MFN treatment, because service providers from nonmembers need to be established in at least one FTA member country first. But if entry conditions in at least one member country are liberal, a non-restrictive rule of origin will de facto afford broad market access within the FTA territory to service providers from non-FTA countries. By contrast, if a restrictive rule of origin is chosen, only a subset of service providers established in an FTA area benefits from liberalization commitments undertaken by member countries. This difference in treatment has both economic and bargaining implications, which will be discussed in turn.

\section{$\underline{\text { Economic implications }}$}

Mattoo and Fink (2004) analyze the economic effects of preferential versus MFN liberalization in services. They draw the following main conclusions, from the viewpoint of the importing FTA member (country B in Figure 2):

- First, relative to the status quo, preferential liberalization in services brings about static welfare gains. This finding differs from the more ambiguous conclusion drawn in the goods case. The key difference is that protection in services does not generate fiscal revenue, as do tariffs on imported goods. Thus, trade diversion effects associated with preferential liberalization in services do not lead to any loss in government revenue that can lead to negative welfare effects in the case of goods.

- Second, MFN liberalization yields greater welfare gains than preferential liberalization. Non-discriminatory market opening does not bias competition from abroad and therefore promotes entry of the most efficient service providers. Additional gains from trade, associated with greater economies of scale and knowledge spillovers, are also likely to be greater if liberalization proceeds on an MFN basis. There is one exception to this conclusion. If 'learning by doing' effects are important, preferential liberalization may enable domestic service suppliers from member countries to become more efficient, as they face some competition from within the FTA territory, but are not yet exposed to global competition. In theory, preferential liberalization can thus prepare infant domestic suppliers for competition at the global level.

- Third, there is a special long-term trade diversion effect to worry about. Preferential liberalization may offer a first-mover advantage to potentially second-best service providers from within the FTA territory. Since many service industries are characterized by high location-specific sunk costs, first-best providers from outside the FTA territory may be deterred from entering the market when trade is eventually liberalized on an MFN 
basis. Thus, even if preferences are temporary, they may have long-term implications for a country's ability to attract the world's most efficient service providers.

What do these conclusions imply for the choice of rule of origin? Unless preferential FTAs are specifically designed to promote learning-by-doing, a liberal rule of origin is in economic terms more desirable. Even though a liberal rule of origin does not fully eliminate discrimination against non-member countries, it does away with some discrimination and therefore enlarges the pool of foreign suppliers competing for access to the domestic market. By contrast, if policymakers believe that their domestic service industries are at an infant stage and cannot be immediately exposed to global competition, a restrictive rule of origin may be a prerequisite for governments to commit to market opening in an FTA. This consideration is relevant for the ASEAN region, where policymakers have frequently advanced learning-by-doing externalities as a motivation for regional integration.

From the viewpoint of the exporting FTA member (country A in Figure 2), additional considerations apply. The choice of rule of origin determines who will benefit from an FTA. One can broadly distinguish between three groups of beneficiaries: national service suppliers, foreign suppliers already established, and foreign suppliers not yet established (more on how these suppliers are defined below). This raises the following issues:

- If service suppliers take the form of firms (juridical persons), a restrictive rule of origin would limit export and associated employment gains to national suppliers (or, more broadly, already established suppliers). This outcome may be sought for non-economic reasons, such as the promotion of certain ethnic groups. In addition, a restrictive rule of origin could also underpin possible ‘learning-by-doing’ effects mentioned above.

By contrast, a liberal rule of origin may attract new FDI from outside the FTA territory. Indeed, a country with liberal entry conditions for suppliers from outside the free trade area may specifically seek to become a hub for companies to access markets within the free trade area. The benefits from this form of FDI would depend on the modes through which services are exported to other FTA members. In the case of Modes 1 and 2, there may be significant employment gains in the exporting country. In the case of Mode 3, employment gains may be small, but governments may still benefit from higher tax revenues. Depending on the nature and purpose of FDI, there may also be important spillover externalities for the host economy.

- If service suppliers take the form of individuals (natural persons), a restrictive rule of origin again limits export gains to nationals, which may be sought for non-economic reasons (see above). However, the effects of a liberal rule of origin are trickier. Hypothetically, if service workers from outside the FTA territory merely used the exporting FTA member as a transit point to other FTA markets, a liberal rule of origin would yield little benefit to this member (unless this type of transit were taxed). Benefits would only arise if service providers from outside the FTA territory had an economic interest in the exporting member - that is, if they spent at least part of their income in the exporting FTA member. From an economic perspective, the center of an individual's economic interest thus seems a more important criterion for a rule of origin than the individual's nationality. 
In sum, from an economic perspective, the choice of rule of origin depends on the objectives attached to an FTA. A liberal rule of origin promotes greater economic efficiency by reducing discrimination and can attract FDI from outside the FTA territory, but it can undermine learningby-doing externalities sought after in an FTA.

\section{Bargaining implications}

There are various reasons why countries engage in bilateral or regional trade negotiations, rather than pursuing liberalization on an MFN basis at the WTO. One is that bargaining may be more productive among a smaller set of countries. The WTO now has 149 members at all levels of development and the multilateral trade agenda has much expanded since the GATT days. Trade negotiations at the multilateral level therefore tend to be complex and time-consuming. For countries ready to commit to market opening in services, a bilateral or regional forum may deliver quicker results.

Another handicap of multilateral negotiations is that countries can free-ride on the bargaining efforts of others. Multilateral services negotiations proceed on a bilateral request and offer basis, but eventual commitments are made on an MFN basis. Thus, even though one WTO member may be interested in improved market access in another member, it may be reluctant to engage in reciprocal bargaining if there are third members interested in the same market access. The end result is a less ambitious negotiating outcome. In principle, FTAs offer a way out, as the smaller number of players reduces the scope for free-riding on the bargaining efforts of others. ${ }^{3}$ However, this assumes that countries not party to an FTA do not benefit from deeper market access negotiated under the FTA. In other words, for free-rider problems to be less severe in a bilateral or regional context, FTAs need to adopt a restrictive rule of origin.

This argument has an important upshot, which is of current relevance to the bargaining situation of several ASEAN countries. Suppose a country negotiates sequentially two or more bilateral FTAs. If it commits to liberal market access in the first FTA and this FTA adopts a liberal rule of origin, the trading partner for the second FTA may be unwilling to 'pay' for making the same commitment in the second FTA. In other words, with a liberal rule of origin, it may not be possible to 'sell' the same market access commitment twice. ${ }^{4}$

In sum, a liberal rule of origin may undermine the bargaining advantages that FTAs offer relative to multilateral trade negotiations.

\section{What are options for rules of origin in services?}

Rules of origin for service suppliers can be defined along a number of criteria. Some guidance is available from existing trade agreements in services—in particular, the 2003 China-Hong Kong Closer Economic Partnership Agreement (CEPA), which arguably has the most detailed rule of

\footnotetext{
${ }^{3}$ This point is more fully elaborated in Mattoo and Fink (2005).

${ }^{4}$ There may still be a benefit for the second FTA partner from replicating the commitment made under the first FTA. It would make the commitment subject to the disciplines of the second FTAs' rules - in particular, possible provisions for the settlement of disputes.
} 
origin seen so far (see Box 1). ${ }^{5}$ For companies (juridical persons), key criteria for rules of origin include:

- Incorporation. A first requirement may simply be for a service supplier to be incorporated under the laws of the exporting FTA member.

- Substantive business operations. This could be defined by the possession of a business or service license in the exporting FTA member, although this would say little about the scale of a service supplier's activities. Additional options include the payment of local profit taxes, the owning or renting of premises, a minimum sales requirement, a minimum number of years of establishment, and a requirement that the export of services within the FTA territory be of the same nature as the services supplied in the exporting FTA member.

- Domestic ownership and control. Eligibility for preferences may be confined to firms that are owned and/or controlled by persons of the exporting FTA member. This is usually defined through the equity share in a company or the voting rights controlled by domestic shareholders. In FTAs involving more than two countries, it is also possible to introduce a more liberal cumulated ownership and control criterion. In other words, eligibility for preferences would be widened to service providers that are majority owned or effectively controlled by persons from FTA member countries.

- Domestic employment. Trade preferences under an FTA may be confined to firms in which a minimum share of employees consists of nationals or local residents.

For individual service suppliers (natural persons), key criteria for rules of origin include:

- Nationality. This can be determined straightforwardly by the passport of an interested service supplier.

- Residency. A residency approach would be broader than a nationality approach, as it would include some foreign nationals present in the exporting FTA member. Options would depend on the forms of residency available in that member. For example, a rule of origin could include permanent residents, but exclude temporary residents.

- Center of economic interest. This would be akin to the concept of substantive business operations in the case of firms. An individual's center of economic interest can be defined by a minimum number of years of residency, the payment of local income taxes, or the owning or renting of a dwelling. In practice, to the extent that a country's residency requirements are rooted in the center of economic interest principle, the two approaches would yield similar outcomes.

As a final note, the GATS imposes certain disciplines on rules of origin that WTO members entering into FTAs may adopt. In particular, WTO members are required to extend trade

\footnotetext{
${ }^{5}$ Beviglia Zampetti and Sauvé (2004) offer a detailed overview of rules of origin in services encountered in existing investment and trade agreements.
} 
preferences to commercially established service suppliers from third countries that engage in substantive business operations within an FTA territory (Article V.6). However, in the case of FTAs involving only developing countries, preferential treatment may, in addition, be limited to companies "owned or controlled by natural persons of the parties" to an FTA (Article V.3b). Interestingly, the GATS does not create any discipline on the rule of origin FTA members may adopt for individual service providers.

\section{Box 1: Rules of origin in the China-Hong Kong Closer Economic Partnership Agreement}

The China-Hong Kong Closer Economic Partnership Agreement is in many ways a special trade agreement. It grants Hong Kong-based service providers preferential access to China's market, in advance of the liberalization schedule to which China committed as part of its accession package to the WTO. China's offer to Hong Kong under CEPA had little to do with classical arguments of trade bargaining. Hong Kong, being one of the most open economies in the world, had little to give in terms of improved market access for Chinese suppliers. Rather, the Agreement was intended to promote deeper integration between the Mainland and Hong Kong and has to be understood in the context of the "one country, two systems" formula.

If CEPA had adopted a liberal rule of origin and given Hong Kong's liberal entry policies, service suppliers from outside of Hong Kong would have had a way to enter the Chinese market in advance of the WTO schedule. This was not the intention of the Chinese and Hong Kong governments. Thus, CEPA has an annex on the definition of service suppliers, which translates into one of the most detailed rule of origin so far seen in a trade agreement. In particular, for Hong Kong companies to enjoy preferential treatment under CEPA, they must have had substantive business operations for 3-5 years in Hong Kong for the services they intend to provide in the Mainland; they must have paid profit tax in Hong Kong; they must own or rent premises for business operations in Hong Kong; and more than 50 percent of employees must be Hong Kong residents (or Chinese people staying in Hong Kong on a one way permit). Additional rules exist for law firms, which require the sole proprietor and all partners of a firm to be registered as practicing lawyers. In the case of individuals (natural persons), eligibility for preferential treatment is confined to Hong Kong permanent residents.

In order to be certified as Hong Kong Service Suppliers under CEPA, interested service suppliers must submit an application to Hong Kong's Department of Trade and Industry, along with documentation which verifies that suppliers meet the above criteria. The Agreement came into force on January 1, 2004. As of May 2005, 788 certificates for Hong Kong Service Suppliers were issued.

Source: Information provided on the website of Hong Kong's Department of Trade and Industry

(http://www.tid.gov.hk/english/cepa/fulltext.html)

\section{What factors determine the relevance and restrictiveness of rules of origin?}

As already indicated, the relevance of a rule of origin for service suppliers depends critically on the pattern of remaining market access restrictions that FTA members maintain against nonmembers. Suppose that these restrictions are identical for all FTA members - the equivalent of a customs union in the case of goods trade. If services can only be delivered through the establishment of a commercial presence (Mode 3), rules of origin would lose their relevance. This is because service providers from outside the FTA territory would not need to establish an intermediate presence in one of the FTA members for the purpose of obtaining better access to other FTA markets. However, they would still be relevant if services can be delivered on a cross-border basis (Mode 1) or through consumption abroad (Mode 2). Because of economies of scale and scope, a service provider from outside the FTA may prefer to serve the whole FTA 
territory from one location, rather than establish a commercial presence in every FTA member. For example, such a scenario would apply to the creation of hub-and-spoke networks for the provision of transport services.

Rules of origin would also not be binding when service suppliers from outside the region would voluntarily establish a presence in the intermediate country and voluntarily access other FTA markets from this presence. But in many circumstances, this will not be the preferred route. Assuming that rules of origin are indeed binding, their de facto restrictiveness is determined by the costs they impose on service suppliers from non-member countries. In general, one can distinguish among the following two types of costs:

- Tax obligations. Exporting services from a subsidiary within the FTA territory rather than from the parent firm outside the FTA territory may lead to different tax obligations. Depending on the tax rules and tax rates prevailing in different jurisdictions, exports from a subsidiary may lead to lower or higher tax payments.

- Business transaction costs. Establishing and maintaining a commercial presence in the intermediate country can create non-trivial transaction costs. For example, a strict definition of 'substantial business operations' may imply greater investments into the local market than a foreign service supplier would undertake voluntarily-especially if the local market is small. A 'domestic ownership and control' requirement would force the foreign service supplier to enter into a (minority) joint venture arrangement with a local partner, which can entail significant transaction costs. Similarly, domestic employment requirements could drive up operational costs, if the service supplier preferred hiring expatriate workers.

Similar considerations apply, in theory, also to individual service providers. But in practice, they seem less relevant for Mode 4 trade, because immigration and residency requirements typically pose a sufficiently high barrier against using an FTA member as a transit point to other FTA markets.

\section{Simulation of different rules of origin in five ASEAN countries}

In order to assess more fully the economic and bargaining implications of alternative rules of origin that may be adopted in FTAs, it is necessary to obtain a better empirical understanding of the issues outlined in the preceding discussion. A research project of the ASEAN Economic Forum research network has taken a first step at providing some empirical guidance, focusing on the rules of origin for juridical persons in selected service sub-sectors. National research studies were conducted in the following five ASEAN countries: Lao PDR, Malaysia, the Philippines, Thailand, and Vietnam. ${ }^{6}$ A core element of these studies is a simulation exercise assessing which service providers would or would not be eligible for preferences negotiated under a region-wide FTA.

\footnotetext{
${ }^{6}$ See, respectively, Douangboupha, Thiengthepvongsa, and Vilavong, (2006), Tham and Zainal Abidin (2006). Avila and Manzano (2006), Arunanondchai and Nikomborirak (2006), Nhu-Van, Chien-Thang, Hoang-Dat (2006).
} 
To motivate the analysis, we first provide some background information on ASEAN economic integration. We then review the different rules of origin that have been adopted in FTAs negotiated by ASEAN countries. The final part of this section describes the simulation setup and summarizes the studies’ main findings.

\section{ASEAN trade and investment policy}

ASEAN is one of the most successful regional groupings among developing countries to date. Its combined GDP totaled US\$ 2.53 trillion, roughly 4.5 of the World GDP, while its exports totaled US\$ 500 billion, approximately 6 percent of total world exports. ${ }^{7}$ ASEAN has made a remarkable achievement in liberalizing trade in goods within the region under the ASEAN Free Trade Agreement (AFTA). In January 2003, tariffs between member countries were reduced to $0-5 \%$ for all products, except those on the general exception and sensitive product lists of each member country. By contrast, the region's record on service sector and investment liberalization is much less impressive. Countries' commitments under the ASEAN Free Trade Agreement in Services (AFAS) improve only marginally on those made in the GATS. ${ }^{8}$ The ASEAN Investment Area (AIA), in principle, became effective in January 2003, but its liberalization content is substantially undermined by extensive lists of exemptions. ${ }^{9}$

Starting in 2001, several of the more ambitious ASEAN members-particularly Singaporehave entered into a series of bilateral free trade agreements with countries outside the ASEAN region, including the United States and Japan (see Table 1). Thailand also signed FTAs with a number of developing countries and is negotiating an FTA with the United States and Japan as well. The trade agreements with the most far-reaching implications for ASEAN service sector liberalization have arguably been those with the United States. For example, the Bilateral Trade Agreements that Laos and Vietnam signed with the US require market access to telecommunications, financial, healthcare, tourism and distribution services. Similarly, the Singapore-US FTA requires across-the-board service market liberalization with only few reservations listed.

\section{What rules of origin have been adopted in existing services agreements?}

As in trade in goods, the rule of origin for services trade in each bilateral or regional free trade agreement may differ, depending on the particular interests of the signatories or their relative bargaining power if interests are divergent. At the same time, in crafting rules of origin in an FTA, members of the WTO are bound by the disciplines of GATS Article V-as discussed above.

The narrowest rule of origin with respect to investment is that which defines origin of a service supplier by the nationality of the person(s) who own or control the service supplier. The Thailand-Australia Free Trade Agreement stipulates that either Party may deny the benefits of

\footnotetext{
${ }^{7}$ CIA World Fact Book 2005.

${ }^{8}$ See Stephenson and Nikomborirak (2002).

${ }^{9}$ For Lao PDR, Vietnam, and Myanmar, the AIA will only become effective in 2010. See Nikomborirak (2004).
} 
pre-establishment national treatment to "an investor of the other Party that is a juridical person of such Party and to investments of such an investor where the Party establishes that the juridical person is owned or controlled by persons of a non-Party". That is, foreign owned or controlled companies incorporated under Australian Law may be denied benefits under the TAFTA. A similar rule of origin is embedded in the India-Singapore Economic Cooperation Agreement, but only for services supplied through commercial presence. ${ }^{10}$ Domestic ownership and control is also required in the Treaty of Amity signed between Thailand and the United States in 1966. The Treaty grants benefits only to American or Thai owned or controlled companies engaging in substantial business operations in either country. Consequently, American companies applying for benefits under the Treaty to invest in a businesses restricted to foreigners would have to prove that the majority of their "ultimate beneficial owners" are indeed American citizens. ${ }^{11}$

Aside from these two agreements, all other services agreements involving ASEAN countries have adopted a rule requiring only substantial business operations in the territory of a Party. In other words, a non-party service supplier which engages in substantial business operations may also benefit from the bilateral free trade agreement. Most FTAs, including the AFAS and FTAs involving the United States and Japan, adopt this rule of origin with only small deviations. It should be noted, however, that even though this broader rule of origin extends trade preferences to third-Party service suppliers, it still discriminates between Party and non-Party suppliers in that the latter can be denied benefits in the absence of proof of substantial business operation, while the former is entitled to the benefit regardless of the size of its business operation in territory of the Party. For example, a subsidiary of an American company operating in a third country, say Citibank operating in Brazil, may also benefit from the Singapore-US Free Trade Agreement (SUSFTA), while a German company, say Siemens, can take advantage of the agreement only through its subsidiary operating in the United States. ${ }^{12}$

None of the FTAs in the ASEAN region defines the term "substantial business operations" more closely-for example, along the lines of the China-Hong Kong CEPA discussed earlier. Implementation is left to FTA parties and, so far, there has not been any jurisprudence on this question. The term "owned and controlled" is also not clearly defined in FTAs. In the JapanSingapore Economic Partnership Agreement (JSEPA), a company is "owned” by persons of a party if more than 50 percent of the equity interest in it is "ultimately owned by the persons of

\footnotetext{
${ }^{10}$ As mentioned in the previous section, Article V.6 of the GATS Agreement requires WTO members to extend the benefits of preferential agreements to foreign owned and controlled service suppliers that engage in substantial business operations in the territory of a member. Preferential agreements involving only developing countries can restrict the benefits to domestically owned and controlled service suppliers. Since Australia would likely be considered a developed country in the WTO, it is not immediately clear how the TAFTA rule of origin complies with the requirements under GATS Article V.6. Compatibility of the rule of origin of the India-Singapore agreement with GATS requirements seems to depend on whether Singapore would be considered a developing country under WTO law (see also footnote 17).

${ }^{11}$ Thailand has scheduled an MFN exemption under the GATS for the preferences granted to the United States under the Treat of Amity. See WTO document GATS/EL/85. However, the "intended" duration of this exemption was 10 years, which expired on January 1, 2005.

${ }^{12}$ Some FTAs of ASEAN countries also allow the denial of benefits to service suppliers that are owned or controlled by persons from countries with which a party does not maintain diplomatic relations.
} 
that party". As for the issue of control, JSEPA stipulates that a company is “controlled” by persons of a Party if such persons have the power to name the majority of its directors or otherwise legally direct its actions. Presumably, this refers to the nationality of the person who can legally represent the company or who is the designated official whose signature must accompany the company's seal on all legal documents.

Finally, most agreements extend benefits to incorporated and non-incorporated legal entities, as long as the substantial business criterion is met. In other words, branches and representative offices of enterprises incorporated in non-parties are typically eligible for FTA preferences. ${ }^{13}$

\section{Simulations of different rules of origin}

The five country case studies undertook a simulation, seeking to investigate the following question: Which of the currently established non-ASEAN service providers would (or would not) benefit from FTA preferences if progressively more restrictive rules of origin were adopted? This is a hypothetical exercise, though it has practical relevance. The ASEAN group is currently negotiating the liberalization of trade in services under the ASEAN-China Comprehensive Economic Cooperation Agreement and the question of which rule of origin to adopt has not been resolved. Additional 'ASEAN-plus' FTAs have been initiated or are envisaged with Australia, India, Japan, Korea and New Zealand. Moreover, even though the AFAS currently maintains a liberal rule of origin, this rule could be changed in the course of future negotiating rounds.

The five country case studies focused on selected service sub-sectors. The choice of sectors was determined by data availability and the need to have at least some non-ASEAN service providers already present in the market.

Table 2 presents the sectors that were analyzed in the five countries as well as the level of openness as measures by the extent of foreign equity ownership allowed. In the end, all five case studies chose banking services for the simulation. Insurance services were analyzed in four countries. Several other sectors - distribution services, maritime shipping services, port and freight forwarding services, health services, and telecommunications services-were covered by at least two studies.

The level of openness varies across countries and sectors. While certain sectors in some countries are open to full foreign ownership, others are restricted to minority equity participation. However, certain caveats to the level of openness described in Table 2 apply. First, foreign investment in services may be restricted by other barriers, notably limits to the number of service suppliers allowed or economic needs tests. Second, Malaysia and Thailand appear to be most restrictive in the participation of foreign equity-especially, in banking and insurance services. At the same time, foreign investors in Thailand are able to secure corporate control despite a 49 percent foreign ownership ceiling through either indirect equity holding involving layers of holding companies up the ownership chain, or through Thai nominees (see also the discussion

\footnotetext{
${ }^{13}$ In particular, most agreements define an enterprise or a juridical person of another party as any legal entity which is constituted or otherwise organized under the law of that other party. One exception is the investment chapter of the Malaysia-Japan Economic Partnership Agreement, which expressly excludes "branches of an enterprise of a third State".
} 
below). In Malaysia, for historical reasons, several established foreign service suppliers hold majority or full equity ownership and their larger foreign equity holdings have been grandfathered. Finally, Vietnam currently does not permit majority foreign ownership in the three sectors shown in Table 5. However, Vietnam is in the final stages of negotiating accession to the WTO and, if past accession agreements are any guide, it may well commit to majority or full foreign ownership in at least some of these sectors.

The criteria for rules of origin simulated are based on those found in the Hong Kong-Mainland CEPA (see previous section), plus an ownership and control criterion. In particular, the simulations adopted the following criteria: ${ }^{14}$

(A) Incorporation under domestic laws

(B) Substantial business operations, as measured by:

(B1) Possession of an operating license

(B2) Minimum capitalization requirement (for financial services)

(B3) Minimum number of years of establishment (3-5 years)

(B4) Owning or renting of premises

(C) Domestic ownership and control, as measured by more than 50 percent of equity holdings

(D) Share of domestic employees greater than 50 percent

As an illustration, Table 3 presents the simulation results for the Philippine's banking sector. The results in this case are relatively straightforward. All but two of the non-ASEAN banks in the Philippines are branches of foreign-incorporated banks. Thus, only two foreign banks would meet the domestic incorporation criterion. The substantial business operations criteria are all met, as they mirror operational requirements under domestic laws and all banks have been operational for at least 5 years. None of the non-ASEAN banks would meet the domestic ownership and control requirement, but all of them employ 50 percent or more Filipino residents.

Overall, three main findings emerge from the five country case studies.

First, the single most relevant rule of origin criterion is domestic ownership and control. In other words, when allowed, non-ASEAN service providers prefer to enter foreign markets through majority or fully owned affiliates, rather than entering into minority joint ventures with local companies. Thus, if a company entered an ASEAN country for the sole purpose of obtaining preferential access to another market and was forced into a minority joint venture, it would most likely depart from its preferred way of doing business and incur certain transaction costs.

\footnotetext{
${ }^{14}$ Depending on data availability and the characteristics of the different sectors, the studies sometimes had to adapt the 'substantial business operations' criterion.
} 
In the case of financial services, incorporation is also a relevant criterion, because foreign service suppliers often enter the domestic market by means of establishing a branch rather than a subsidiary. An exception is Malaysia, because the establishment of branches by foreignincorporated financial institutions is restricted by law. In the case of Laos, the Philippines, Thailand, and Vietnam, a rule of origin that expressly excludes branches leads to a marked reduction in the number of service providers eligible for FTA benefits.

To illustrate the importance of these two criteria, Table 4 presents the number of non-ASEAN service providers that are domestically owned and controlled, foreign owned and controlled, and branches of foreign-incorporated enterprises.

Most other criteria are relatively easily met—partly because they are already operational requirements under domestic laws. The number of years of establishment is generally not restrictive if kept at a minimum of 5 years because most foreign companies operating in the selected sectors have had commercial presence over a longer period of time. This reflects the fact that most ASEAN countries partially opened up their service markets in the 1990s or even earlier. At the same time, the simulation studies applied the different rules of origin criteria to established service providers only. A substantive business operations requirement would still be relevant in restricting the entry of shell companies that merely seek to exploit the trade preferences available under an FTA.

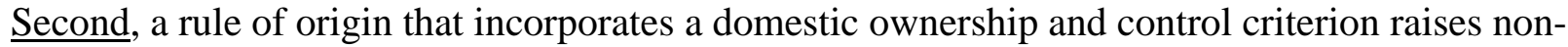
trivial implementation questions. In classifying service providers as domestically owned and controlled, the five country case studies mostly relied on information on direct (or immediate) equity holdings. Data on indirect equity holdings and ultimate shareholders are typically not available to the public. Thus, companies that may appear to be domestically owned and controlled may ultimately be foreign owned and controlled. The deviation between the origins of the immediate shareholders versus ultimate shareholders is likely to be prominent where restrictions on foreign equity participation prevail. Through multi-level equity holdings, foreign investors can manage to exercise corporate control of service providers, in the absence of a direct majority equity ownership.

Thailand is a prominent example of this phenomenon. In principle, foreign equity participation in most service sectors in Thailand is limited to a minority stake (see Table 2). However, foreign companies have managed to exercise control over companies that are directly majority owned by Thai natural or juridical persons. According to Nikomborirak and Tawannakul (2006), foreign controlled public companies — as revealed by the composition of the board of directors and the nationality of director(s) whose signature must accompany all legal documents binding a company-accounted for 17.48 per cent of the market capitalization of the Stock Exchange of Thailand (SET). However, only 2.39 percentage points of the 17.48 percent figure represent direct foreign equity holdings. Interestingly, the circumvention of statutory ownership restrictions does not only involve multi-level equity holdings, but also share ownership by Thai "nominees" who act on behalf of foreign persons. Even though such nominee arrangements are against Thai laws, they appear to have been common practice in Thailand — as is illustrated by the landmark sale of Shin Corporation, the flagship company of the business empire of former Thai Prime Minister Thaksin Shinawatra (see Box 2). 


\section{Box 2: The Deal of the Century-Temasek's Acquisition of Thai Shin Corporation}

In January 2006, the family of former Thai Prime Minister Thaksin Shinawatra decided to sell 47.7 percent of its equity share in Shin Corporation, the flagship of the family's business empire, to Temasek, the Singapore's Government investment arm, for US\$ 1.8 billion. The nationality of the politically charged company immediately became the focus of public scrutiny since Singtel, the Singaporean state-owned telecommunications operator, already owned a 20 percent equity share in Shin Corp prior to the block sale. Shin Corp's nationality will directly affect many of its subsidiaries - such as the cellular phone operator, AIS, television channel operator, ITV, satellite operator Shin Satellite, and low cost airline operator, Thai Air Asia as they are all engaged in service businesses where the Thai Foreign Business Act 1999 restricts direct foreign equity ownership to 49 percent. If Shin Corp were to be considered a foreign-owned company, then the foreign equity limit of all its subsidiaries would have been breached.

To get around the Thai law that limits foreign direct equity holding of $49 \%$, the deal detailed a very complex structure as shown in the following exhibition:

\section{Ownership Chain of AIS, a cellular phone subsidiary of Shin Corp}

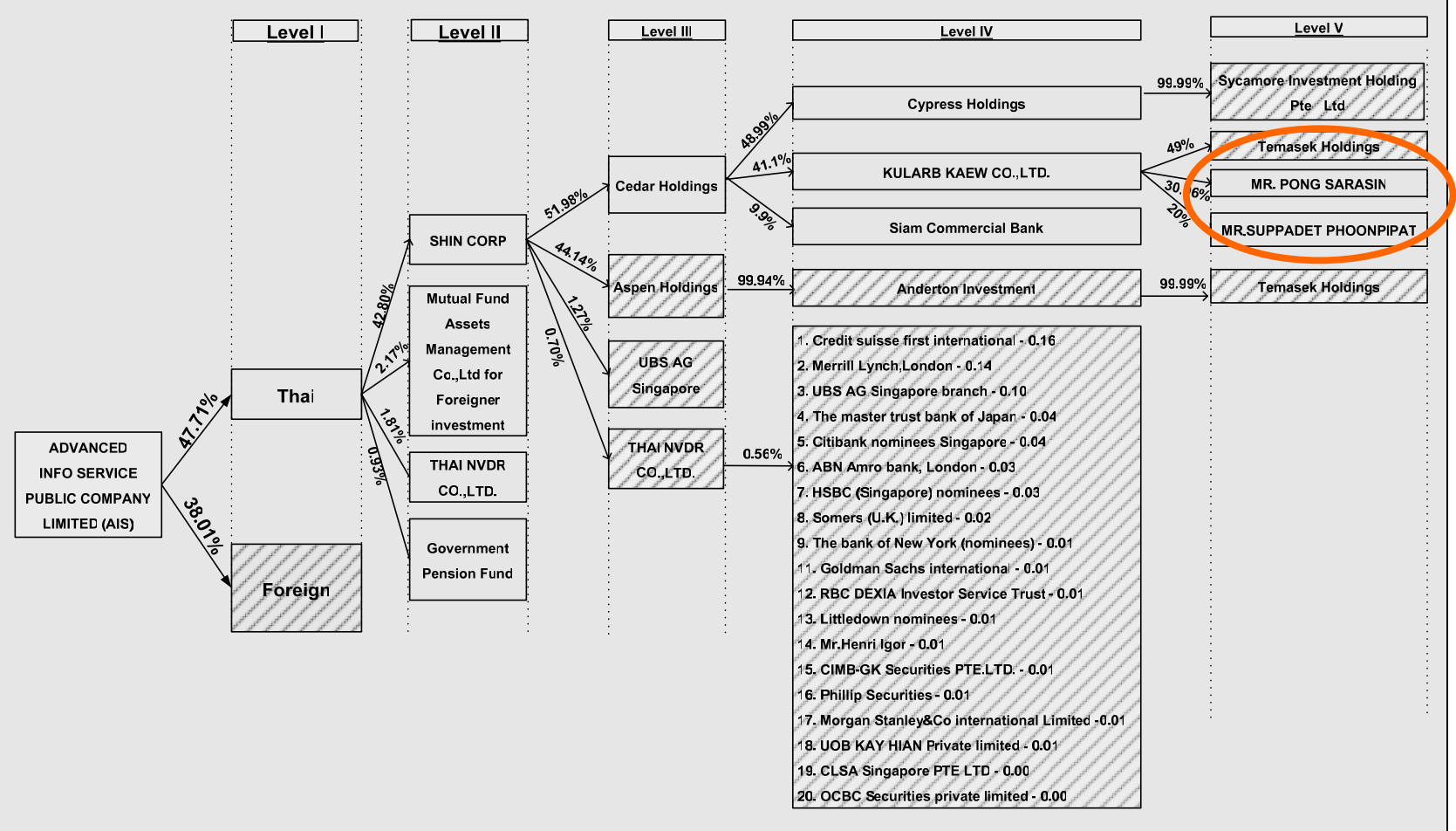

Source: Nikomborirak and Tawannakul (2006).

As can be seen from the illustration, the Shin Corp deal was structured with several layers of foreign equity holding up the company's ownership chain to ensure Temasek's effective corporate control while complying with the 49 percent foreign equity restriction. To begin with, to ensure that Shin Corp remained a Thai legal entity, Cedar Holding was created to assume the 51 percent Thai equity share, while Temasek owned the remaining 44.14 percent foreign equity share through Aspen Holding and Anderton Investment. In addition, to ensure that Cedar holding was in turn a Thai legal entity, Temasak managed to find a genuine Thai partner, Siam Commercial Bank PCL that agreed to hold 9.9 percent of Cedar holding's equity. The remaining $41.1 \%$ mandatory Thai equity share went to a 
dubious newly registered company called "Kularb Kaew" (glass rose), where Temasek owns another 49 percent minority share as expected.

The two major Thai shareholders of Kularb Kaew are two Thai individuals—Mr. Pong Sarasin and Mr. Supadej Phoonpipat. However, their share ownership has created legal controversy, because they are believed not to be genuine Thai partners, but nominees acting on behalf of Temasek. Circumstantial evidence supports this contention. First, both Thai shareholders were allocated in total only 10 percent of the voting shares, rendering effective corporate control in the hands of the foreign partner. Second, both agreed to receive only a fixed 3 percent return on their capital investment, a rate which was lower than the risk-free 1-year government bond. Doubts have also been raised about the ability of the duo to mobilize the billions of Thai baht required to purchase such large equity shares in the company.

While foreign indirect equity holding through holding companies is not counted towards the statutory foreign equity limit and effective corporate control is not prohibited according to Thai law, equity holding through Thai nominees is subject to criminal penalties for both the foreign investor and the Thai nominees. The Ministry of Commerce launched an investigation into the alleged nominee case. By tracing the financial trail of the funds used for the purchase of the Thai equity share in Kularb Kaew, the investigation concluded that the two Thai individuals were indeed nominees for Temasek. The final court ruling on this case is still pending. It could lead to the imprisonment of the two Thai partners. In addition, the future of many Shin Corp subsidiaries operating in the restricted service sector could be jeopardized-possibly even leading to the revocation of cellular, satellite, broadcasting and air transport licenses.

If an FTA adopts a rule or origin that uses an immediate domestic ownership and control criterion, service suppliers that are ultimately foreign owned and controlled may still benefit. The same issue arises under a cumulated ownership and control criterion at the regional level: service suppliers that are ultimately owned and controlled by persons from outside the region may still benefit. The concept of ownership and control is not well developed in ASEAN countries' legal and statistical frameworks. As revealed by the case studies, information on the ultimate ownership of companies is typically not published. ${ }^{15}$ The same is true for information on the details governing corporate control — such as the composition of the board of directors or the nationality of the director(s) whose signature must accompany all legal contracts binding a company. A related problem is posed by service suppliers whose equity is publicly traded. Share ownership may be diffused across a large number of countries, may change hands frequently, and no single shareholder may exercise control over the company.

Nonetheless, one way to effectively implement an ultimate domestic (or regional) ownership and control criterion is to place the burden of proof on the service providers that seek to benefit from an FTA. For example, under the Treaty of Amity between Thailand and the United States, it is up to companies to prove that they are ultimately owned and controlled by residents of either party. Similarly, the certification system under the Hong Kong-Mailand CEPA puts the onus on companies to prove that they meet the rules of origin of the agreement (see Box 1). ${ }^{16}$

\footnotetext{
${ }^{15}$ In Thailand, the Government's database of registered companies assigns the nationality of a legal entity only by the place of incorporation. See Arunanondchai and Nikomborirak (2006).

${ }^{16}$ Note that an ultimate ownership and control test may also be necessary for a rule of origin that merely requires that non-party service suppliers engage in substantial business operations. As discussed in the text, there may be domestically owned and controlled service suppliers that do not engage in substantial business operations in the domestic territory, but that may wish to exploit the preferences available under an FTA.
} 
Third, there is some evidence that non-ASEAN service providers may find it costly to use one ASEAN country as a hub to obtain preferential access to another ASEAN country. The case study for the Philippines analyzed to what extent the non-ASEAN foreign banks present in the Philippines are also present in other ASEAN countries (Avila and Manzano, 2006). As shown in Table 5, most of the banks in question already have a presence in the other markets-at least in the commercially significant ones. The investments in these countries were not effectuated by the Filipino affiliates of the banks. In other words, if non-ASEAN banks were to use their Filipino affiliates to obtain preferential access to other markets, they would likely depart from their preferred global corporate structure.

This point is reinforced by evidence on the tax treatment of corporate income in Thailand and the United States. Suppose a US service provider considers investing in, say, Indonesia either from its parent in the US or from its subsidiary in Thailand. The United States government collects corporate income tax on a global basis. But US subsidiaries in Thailand also pay income tax to the Thai government as they are considered a Thai legal entity. Hence, there is double taxation of income generated by US subsidiaries in Thailand. Although a bilateral tax treaty allows US companies to claim credits for taxes paid to the Thai government, the procedures can be costly and any tax dues exceeding the applicable US rate would not be reimbursed. In addition, Thailand imposes a $10 \%$ withholding tax on profits repatriated overseas. This represents additional costs that the company would have to bear if returns from a particular investment had to be transferred to the parent company in the future (see Arunanondchai and Nikomborirak, 2006).

\section{Conclusions}

As governments enter into negotiations to establish bilateral or regional FTAs covering trade in services, they need to decide to what degree non-parties should benefit from the preferential treatment established by these agreements. For countries in the ASEAN region, this question applies at two levels. First, as reaffirmed by ASEAN Economic Ministers in August 2006, ASEAN countries are committed to establishing free regional trade in services by 2015 . Second, ASEAN as a whole has entered into services negotiations with China and additional negotiations with Australia, Japan, Korea, India, and New Zealand may well be launched.

Progress towards integrating regional service markets has so far been marginal. Would a more restrictive rule of origin make any difference in this context? Two arguments can be made. First, some countries in the region such as Singapore are already open to foreign participation in services and host to many of the world's most efficient service suppliers. Vietnam will likely commit to open service markets upon acceding to the WTO. Other countries are more reluctant to open up, fearing the displacement of domestic service providers. A restrictive rule of origin may assuage the concerns of the latter countries, as liberalization would be partial in terms of the set of service suppliers allowed to enter. Second, a more restrictive rule of origin may limit the scope for free-riding by countries outside the ASEAN region, which are negotiating with ASEAN countries at the WTO or in the context of bilateral FTAs. 
Having said this, the five case studies discussed in this paper suggest that the most restrictive criterion for a rule of origin is domestic ownership and control. Ignoring implementation challenges, it is not clear whether a domestic ownership and control criterion would satisfy the disciplines of GATS Article V. This will depend on whether the FTA in question would be an agreement involving developing countries only. ${ }^{17}$ In addition, a restrictive rule of origin would come with certain economic costs: it may promote the entry of second-best service providers or force first-best service providers to depart from their most efficient global corporate structures. These outcomes would diminish the gains from service market opening in services.

While the studies reviewed in this paper present insightful evidence on an understudied topic, more research is needed to provide better guidance to policymakers on the benefits and costs of different rules of origin in services trade. From an economic perspective, the choice of rule of origin is closely linked to the broader question of the dynamic effects of trade policies in services. The limited evidence available suggests a higher overall growth potential for economies with open service markets (Mattoo et al., 2001). But little is known about the relevance of learning-by-doing effects in specific service sectors and their potential size in relation to the efficiency costs of trade protection. Equally, little is known about the relevance and size of trade diversion costs from preferential treatment in services. Surveys of multinational companies could shed greater light on the tax implications and business transaction costs associated with different geographical structures of corporations. In addition, case studies of past preferential treatment in services could shed light on whether a first-mover advantage has affected the performance of service markets even after entry was liberalized on an MFN basis.

\footnotetext{
${ }^{17}$ A critical question in this respect is whether Singapore could be considered a developing country under the GATS. The WTO has a formal list only of least-developed countries (LDCs), based on United Nations criteria. In principle, non-LDC WTO members can decide for themselves whether they are to be considered 'developed' or 'developing' countries. In this context, it is interesting to note that Singapore has already entered into one FTA hat has incorporated an ownership and control criterion (see footnote 10). However, a member's decision on developing country status may be challenged by other members. So far, there has been no jurisprudence that could give guidance on what criteria would be used to resolve a disagreement on this question.
} 


\section{References}

Arunanondchai, Jutamas and Deunden Nikomborirak. (2006). “Thailand’s Rules of Origin in Services in Regional and Bilateral Trade Agreements.” Mimeo.

Avila, John Lawrence and George Manzano. (2006). "Rules of Origin in Services: A Philippine Perspective.” Mimeo.

Beviglia Zampetti, Americo and Pierre Sauvé. (2006). "Rules of Origin for Services: A Review of Current Practice,” In Estevadeordal, Antoni et al., (eds). The Origin of Goods. (London: Oxford University Press and CEPR), pp. 114-145.

Douangboupha, Latthana, Thavichanh Thiengthepvongsa, and Buavanh Vilavong. (2006). "Rules of Origin in Services Regional Trade Agreements: The Practices in Laos.” Mimeo.

Mattoo, Aaditya, Randeep Rathindran and Arvind Subramanian. (2001). "Measuring Services Liberalization and Its Impact on Economic Growth.” Policy Research Working Paper, No. 2655. (The World Bank).

Mattoo, Aaditya and Carsten Fink (2004). "Regional Agreements and Trade in Services: Policy Issues.” Journal of Economic Integration. Vol. 19, No. 4, pp. 742-779.

Mattoo, Aaditya and Sacha Wunsch-Vincent. (2004). "Pre-Empting Protectionism in Services: The GATS and Outsourcing.” Journal of International Economic Law, Vol. 7, No. 4, pp.765800.

Nhu-Van, Dang, Nguyen Chien-Thang, Vu Hoang-Dat. (2006). "Rule of Origin in Services: Selected Sectors in Vietnam's Case.” Mimeo.

Nikomborirak, Deunden. (2004). “An Assessment of the Investment Regime: Thailand Country Report.” Available at www.iisd.org/pdf/2004/investment_country_report_thailand.pdf.

Nikomborirak, Deunden and Suneeporn Tawannakul. (2006). “The Face of Foreign Companies in the Thai Economy." Paper presented at the Mid-year Conference of the Thailand Development Research Institute, August 25, 2006 (in Thai only).

Stephenson, Sherry and Nikomborirak, Deunden. (2002). "Regional Liberalization in Services.” In Sherry Stephenson, Christopher Findlay and Soonhwa Yi (eds). Services Trade Liberalisation and Facilitation. (Asia Pacific Press at Australian National University).

Tham, Siew Yean and Mahani Zainal Abidin. (2006). "Rules of Origin in Services: Case of Malaysia.” Mimeo. 
Table 1: Free Trade Agreements of ASEAN countries

\begin{tabular}{ll}
\hline Signed agreements & Status \\
ASEAN Framework Agreement on Services & Signed in 1995, subsequently ratified in all countries \\
& except Malaysia \\
Singapore-Australia & Entered into force in 2003 \\
Singapore-Brunei-Chile-New Zealand & Signed in 2005 \\
Singapore-EFTA & Entered into force in 2003 \\
Singapore-India & Signed in 2005 \\
Singapore-Japan & Entered into force in 2002 \\
Singapore-Jordan & Entered into force in 2005 \\
Singapore-Korea & Entered into force in 2006 \\
Singapore-New Zealand & Entered into force in 2001 \\
Singapore-Panama & Signed in 2006 \\
Singapore-United States & Entered into force in 2004 \\
Malaysia-Japan & Entered into force in 2006 \\
Thailand-Australia & Entered into force in 2005 \\
Vietnam-United States* & Entered into force in 2001 \\
Laos-United States* & Entered into force in 2005 \\
Under preparation/negotiation & Partner countries \\
Singapore & Bahrain, Canada, Egypt, Kuwait, Mexico, Pakistan, \\
Indonesia & Peru, Qatar, Sri Lanka, United Arab Emirates \\
Malaysia & Australia, Japan \\
Thailand & Australia, United Status \\
Philippines & India, Japan, United States, Peru, Mexico, South \\
ASEAN & Africa \\
\hline & Japan \\
Australia, China, Japan, Korea, New Zealand, India \\
\hline
\end{tabular}

Notes: Only FTAs with a substantial services component are included. Technically, the Vietnam-US and Laos-US agreements are not free trade agreements, but bilateral trade agreements. 


\section{Table 2: Foreign equity participation allowed in selected service sectors}

\begin{tabular}{|c|c|c|c|c|c|c|c|}
\hline \multirow[b]{2}{*}{ Country } & \multicolumn{2}{|c|}{ Financial services } & \multirow[b]{2}{*}{$\begin{array}{c}\text { Distribution } \\
\text { services }\end{array}$} & \multicolumn{2}{|c|}{ Maritime transport } & \multirow[b]{2}{*}{$\begin{array}{c}\text { Health } \\
\text { services }\end{array}$} & \multirow[b]{2}{*}{ Telecoms } \\
\hline & Banking & Insurance & & $\begin{array}{l}\text { Shipping } \\
\text { services }\end{array}$ & $\begin{array}{l}\text { Port and freight } \\
\text { forwarding } \\
\text { services }\end{array}$ & & \\
\hline Laos & $50 \%$ & $49 \%$ & na & na & na & $100 \%$ & $49 \%$ (a) \\
\hline Malaysia & $30 \%$ (b) & $30 \%$ (b) & $70 \%$ (b) & na & na & $30 \%$ (b) & na \\
\hline Philippines & $100 \%$ & $100 \%$ & $100 \%$ & $40 \%$ & $40 \%$ & na & na \\
\hline Thailand & $25 \%$ & $25 \%$ & $100 \%(c)$ & $49 \%$ & $49 \%$ & $49 \%$ & $49 \%$ \\
\hline Vietnam & $50 \%$ & na & na & $49 \%$ & $49 \%$ & na & na \\
\hline
\end{tabular}

Notes: (a) Higher foreign equity participation is in principle allowed, but subject to government approval. (b) For historical reasons, higher foreign equity participation and even full foreign ownership may exist for already established foreign service suppliers. (c) Wholly owned foreign distributors are allowed only when registered capital exceeds 100 million baht (roughly US\$2.5 million)

Sources: Douangboupha, Thiengthepvongsa, and Vilavong, (2006), Tham and Zainal Abidin (2006). Avila and Manzano (2006), Arunanondchai and Nikomborirak (2006), Nhu-Van, Chien-Thang, Hoang-Dat (2006). 
Table 3: Simulation of rules of origin for non-ASEAN foreign banks in the Philippines:

\section{Criteria for rules of origin}

\begin{tabular}{|c|c|c|c|c|c|c|c|c|}
\hline \multirow[b]{2}{*}{ Bank } & \multirow[b]{2}{*}{$\begin{array}{l}\text { Country of } \\
\text { origin }\end{array}$} & \\
\hline & & A & B1 & B2 & B3 & B4 & C & $\mathbf{D}$ \\
\hline ANZ Banking Group, Ltd. & Australia & & Q & Q & $\mathrm{Q}$ & $\mathrm{Q}$ & & $\mathrm{Q}$ \\
\hline Bank of America, N.A. & USA & & Q & Q & Q & Q & & $\mathrm{Q}$ \\
\hline Bank of China - Manila Branch & China & & $\mathrm{Q}$ & $\mathrm{Q}$ & $\mathrm{Q}$ & $\mathrm{Q}$ & & $\mathrm{Q}$ \\
\hline $\begin{array}{l}\text { Bank of Tokyo-Mitsubishi, Ltd.- } \\
\text { Manila Branch }\end{array}$ & Japan & & Q & $\mathrm{Q}$ & $\mathrm{Q}$ & Q & & $\mathrm{Q}$ \\
\hline Citibank, N.A. (Phils.) & USA & & $\mathrm{Q}$ & $\mathrm{Q}$ & $\mathrm{Q}$ & $\mathrm{Q}$ & & $\mathrm{Q}$ \\
\hline Deutsche Bank AG & Germany & & Q & Q & Q & Q & & $\mathrm{Q}$ \\
\hline $\begin{array}{l}\text { International Commercial Bank } \\
\text { of China }\end{array}$ & Taipei & & Q & Q & $\mathrm{Q}$ & Q & & $\mathrm{Q}$ \\
\hline JP Morgan Chase Bank & USA & & $\mathrm{Q}$ & $\mathrm{Q}$ & $\mathrm{Q}$ & $\mathrm{Q}$ & & $\mathrm{Q}$ \\
\hline Korea Exchange Bank & S Korea & & $\mathrm{Q}$ & $\mathrm{Q}$ & $\mathrm{Q}$ & $\mathrm{Q}$ & & Q \\
\hline $\begin{array}{l}\text { Mizuho Corporate Bank, Limited } \\
\text { - Manila Branch (Fuji Bank) }\end{array}$ & Japan & & $\mathrm{Q}$ & $\mathrm{Q}$ & Q & Q & & Q \\
\hline ING Bank N.V.-Manila Branch & Netherlands & & $\mathrm{Q}$ & $\mathrm{Q}$ & $\mathrm{Q}$ & $\mathrm{Q}$ & & Q \\
\hline Standard Chartered Bank & $\begin{array}{l}\text { United } \\
\text { Kingdom }\end{array}$ & & $\mathrm{Q}$ & $\mathrm{Q}$ & $\mathrm{Q}$ & $\mathrm{Q}$ & & Q \\
\hline $\begin{array}{l}\text { The Hongkong and Shanghai } \\
\text { Banking Corporation, Ltd. }\end{array}$ & Hongkong & & $\mathrm{Q}$ & Q & Q & Q & & Q \\
\hline ABN-AMRO Bank, Inc. & Netherlands & & $\mathrm{Q}$ & $\mathrm{Q}$ & $\mathrm{Q}$ & Q & & Q \\
\hline $\begin{array}{l}\text { Chinatrust (Phils.) Commercial } \\
\text { Bank Corporation }\end{array}$ & Taipei & $\mathrm{Q}$ & $\mathrm{Q}$ & $\mathrm{Q}$ & $\mathrm{Q}$ & $\mathrm{Q}$ & & Q \\
\hline HSBC Savings Bank (Phil) & Hong Kong & Q & $\mathrm{Q}$ & $\mathrm{Q}$ & $\mathrm{Q}$ & $\mathrm{Q}$ & & Q \\
\hline
\end{tabular}

Notes: “Q” means qualified under the particular criterion heading. The different criteria for rules of origin are described in the text. For criterion B3, the minimum capital requirements are those set by prudential banking regulations in the Philippines.

Source: Avila and Manzano (2006). 
Table 4: Type of ownership and legal entity of non-ASEAN service providers

\begin{tabular}{|c|c|c|c|}
\hline & $\begin{array}{l}\text { Domestically owned } \\
\text { and controlled }\end{array}$ & $\begin{array}{l}\text { Foreign owned and } \\
\text { controlled }\end{array}$ & $\begin{array}{l}\text { Branches of foreign- } \\
\text { incorporated } \\
\text { enterprises }\end{array}$ \\
\hline \multicolumn{4}{|l|}{ Banking } \\
\hline Laos & 6 & 0 & 5 \\
\hline Malaysia & 5 & 13 & 0 \\
\hline Philippines & na & 7 & 15 \\
\hline Thailand & 9 & 2 & 18 \\
\hline Vietnam & 2 & 7 & 25 \\
\hline \multicolumn{4}{|l|}{ Insurance } \\
\hline Thailand & 23 & 7 (a) & 1 \\
\hline Philippines & 120 & 14 & 6 \\
\hline Laos & 0 & 1 & 0 \\
\hline Malaysia & 15 & 10 & 2 \\
\hline \multicolumn{4}{|c|}{ Distribution services } \\
\hline Thailand & 9 & $10(a)$ & 0 \\
\hline Malaysia & 6 & 7 & 0 \\
\hline \multicolumn{4}{|c|}{ Telecommunications services } \\
\hline Thailand & 4 & 2 & 0 \\
\hline Laos & 2 & 2 & \\
\hline \multicolumn{4}{|c|}{ Freight forwarding services } \\
\hline Malaysia & 1 & 3 & 2 \\
\hline Thailand & 120 & 5 (a) & 0 \\
\hline \multicolumn{4}{|l|}{ Health services } \\
\hline Laos & 24 (public) & 5 & 0 \\
\hline Malaysia & 33 & 2 & 0 \\
\hline
\end{tabular}

Note: (a) Service providers are controlled by a foreign person but legally a Thai company since foreign equity share is less than $49 \%$. This occurs because Thai laws prohibit majority foreign equity holdings in all service sectors. Therefore, MNCs must invest through indirect equity holding using holding companies (legal in Thailand) or nominees (technically illegal).

Sources: Douangboupha, Thiengthepvongsa, and Vilavong, (2006), Tham and Zainal Abidin (2006). Avila and Manzano (2006), Arunanondchai and Nikomborirak (2006), Nhu-Van, Chien-Thang, Hoang-Dat (2006). 
Table 5: ASEAN presence of non-ASEAN banks established in the Philippines

\begin{tabular}{|c|c|c|c|c|c|c|c|}
\hline Bank & Brunei & Indonesia & Malaysia & Singapore & Thailand & Myanmar & Vietnam \\
\hline ANZ Banking Group, Ltd. & yes & yes & yes & yes & yes & & yes \\
\hline Bank of America, N.A. & & yes & yes & yes & yes & & \\
\hline $\begin{array}{l}\text { Bank of China - Manila } \\
\text { Branch }\end{array}$ & & yes & yes & yes & yes & & yes \\
\hline $\begin{array}{l}\text { Bank of Tokyo-Mitsubishi, } \\
\text { Ltd.-Manila Branch }\end{array}$ & & yes & yes & yes & yes & yes & yes \\
\hline Citibank, N.A. (Phils.) & yes & yes & yes & yes & yes & & yes \\
\hline Deutsche Bank AG & & yes & yes & yes & yes & & yes \\
\hline $\begin{array}{l}\text { International Commercial } \\
\text { Bank of China }\end{array}$ & & & yes & yes & yes & & yes \\
\hline JP Morgan Chase Bank & & yes & yes & yes & yes & & yes \\
\hline Korea Exchange Bank & & yes & & yes & & & yes \\
\hline $\begin{array}{l}\text { Mizuho Corporate Bank, } \\
\text { Limited - Manila Branch } \\
\text { (Fuji Bank) }\end{array}$ & & yes & yes & yes & yes & & yes \\
\hline $\begin{array}{l}\text { ING Bank N.V.-Manila } \\
\text { Branch }\end{array}$ & & & yes & yes & yes & & \\
\hline Standard Chartered Bank & yes & yes & yes & yes & yes & & yes \\
\hline $\begin{array}{l}\text { The Hongkong and } \\
\text { Shanghai Banking } \\
\text { Corporation, Ltd. }\end{array}$ & yes & yes & yes & yes & yes & & yes \\
\hline ABN-AMRO Bank, Inc. & & yes & yes & yes & yes & & yes \\
\hline $\begin{array}{l}\text { Chinatrust (Phils.) } \\
\text { Commercial Bank } \\
\text { Corporation }\end{array}$ & & yes & & & & & yes \\
\hline
\end{tabular}

Source: Avila and Manzano (2006). 
Figure 1: Rules of origin for cross-border trade

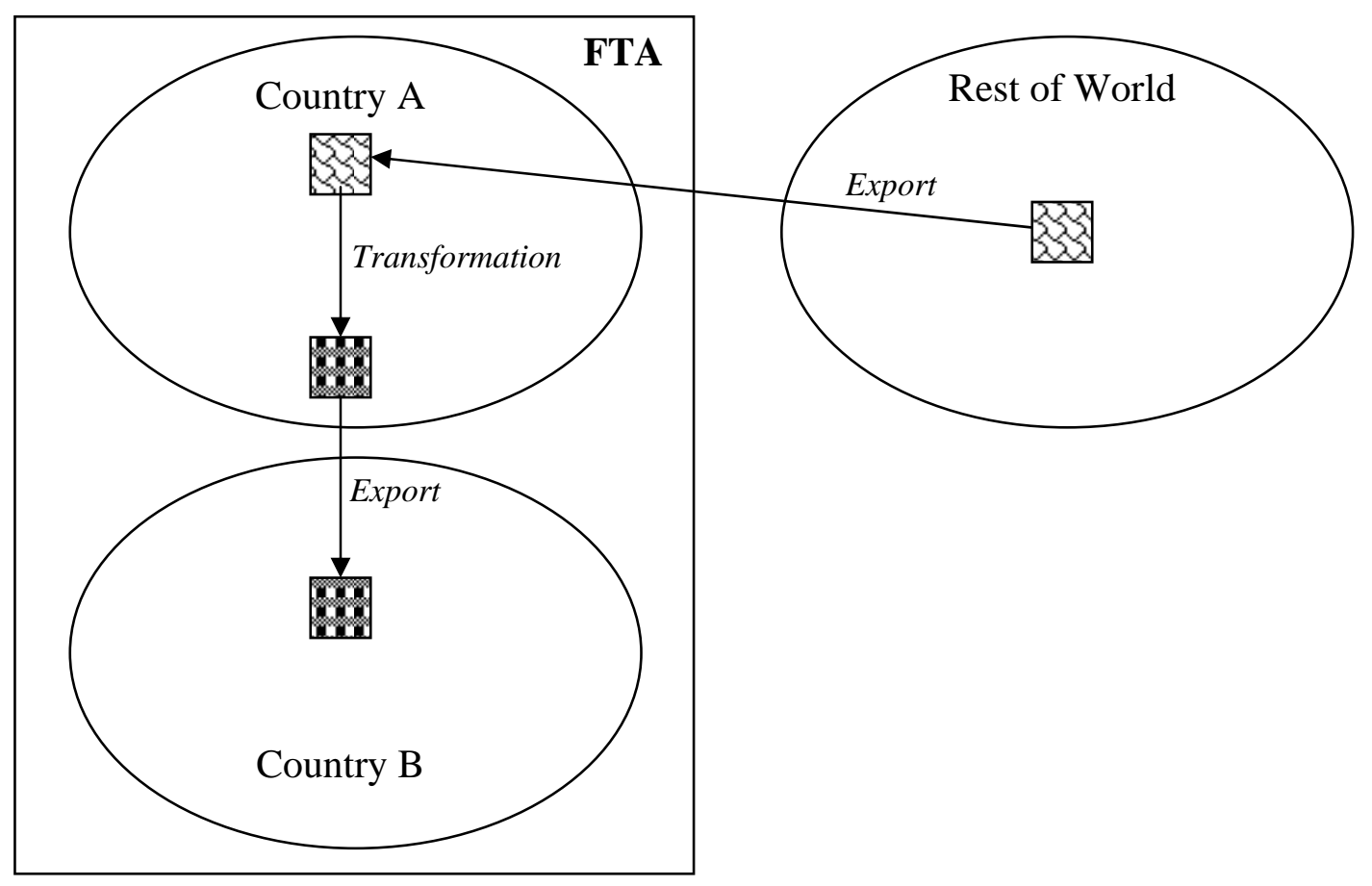


Figure 2: Rules of origin for service suppliers

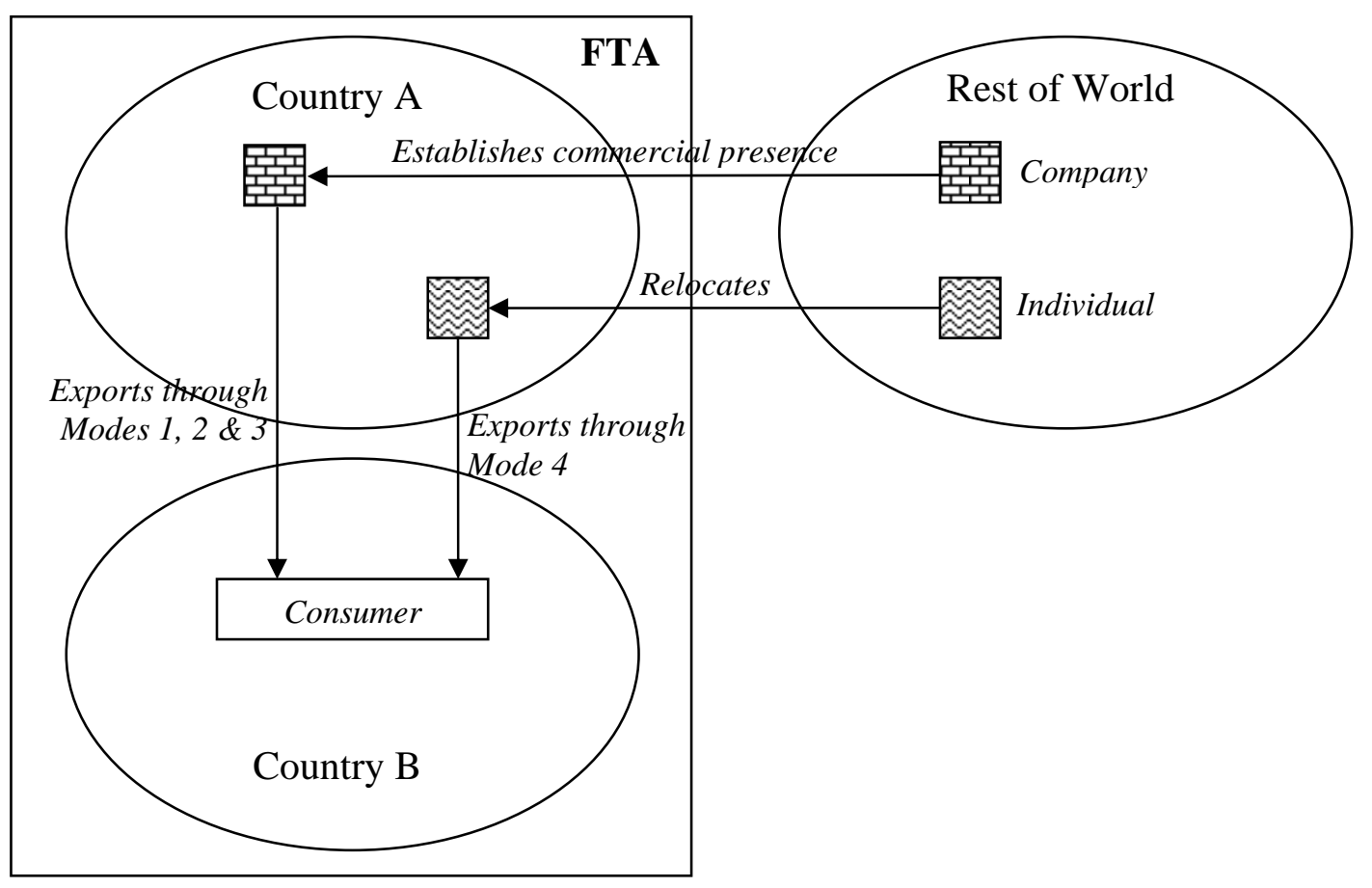

